\title{
Kejadian perdarahan uterus abnormal di RSUP Prof. Dr. R. D. Kandou Manado tahun 2015
}

\author{
${ }^{1}$ Genuine G. E. Tendean \\ ${ }^{2}$ Maya Mewengkang \\ ${ }^{2}$ John J. E. Wantania
}

\author{
${ }^{1}$ Kandidat Skripsi Fakultas Kedokteran Universitas Sam Ratulangi Manado \\ ${ }^{2}$ Bagian Obstetri dan Ginekologi Fakultas Kedokteran Unversitas Sam Ratulangi Manado \\ Email: genuine.tendean0812@gmail.com
}

\begin{abstract}
Abnormal uterine bleeding (AUB) is the most frequent gynecologic symptoms in women of reproductive age outpatients with a prevalence of 11 of 13 women and is increasing with aging reaching $25 \%$ among women of reproductive age. This study was aimed to describe cases of AUB at Prof. Dr. R. D. Kandou Hospital Manado in 2015. This was a retrospective descriptive study using secondary data of the medical records. The results showed that there were 62 cases of AUB. Most of them were at the age of 41-50 years $(33.87 \%)$ meanwhile the minimum were $<20$ years and $21-30$ years $(9.68 \%)$. Based on BMI, the highest percentage was BMI 23.0-24.9 (30\%). For AUB classification PALMCOEIN, the majority were PUA-L (40\%). Histological examination was performed in $30.76 \%$. The most common treatment was medicated therapy and D \& C (34.62\%). Conclusion: In this study, the majority of AUB cases were aged 41-50 years, BMI of 23.0 to 24.9, and PALM-COEIN classification of PUA-L, and medicated therapy plus D \& C.
\end{abstract}

Keywords: prevalence, abnormal uterine bleeding

\begin{abstract}
Abstrak: Perdarahan uterus abnormal (PUA) merupakan gejala ginekologik yang paling sering pada pasien rawat jalan wanita usia reproduksi dengan prevalensi 11 dari 13 wanita. Kejadian PUA meningkat dengan berjalannya usia, mencapai $25 \%$ pada wanita usia reproduksi. Penelitian ini bertujuan untuk mengetahui gambaran pasien PUA di RSUP. Prof. Dr. R. D. Kandou Manado tahun 2015. Jenis penelitian ialah deskriptif retrospektif dengan menggunakan data rekam medik. Hasil penelitian menunjukkan terdapat 62 data kasus PUA. Berdasarkan usia, terbanyak usia 41-50 tahun (33,87\%) dan yang paling sedikit usia $<20$ tahun dan 21-30 tahun (9,68\%). Berdasarkan IMT, IMT 23,0-24,9 yang paling tinggi (30\%). Untuk klasifikasi PUA PALM-COEIN, terbanyak ialah PUA-L (40\%). Pasien yang melakukan pemeriksaan histopatologik sebanyak $30,76 \%$ dan yang tidak melakukan pemeriksaan $69,24 \%$. PUA dengan penanganan medikamentosa dan D\&C memiliki persentase terttinggi $(34,62 \%)$. Simpulan: Pada studi ini, kejadian PUA terbanyak pada usia 41-50 tahun, IMT 23,0-24,9, klasifikasi PUA-L, dengan pilihan penanganan terbanyak medikamentosa dan D\&C.
\end{abstract}

Kata kunci: kejadian, PUA

Perdarahan uterus abnormal (PUA) merupakan gejala ginekologik yang paling sering pada wanita usia reproduksi pada pasien rawat jalan dengan prevalensi 11 dari 13 wanita. Data ini meningkat dengan berjalannya usia, mencapai $25 \%$ pada wanita usia reproduksi. ${ }^{1}$ Berdasarkan data dari klinik Ginekologi Rumah Sakit Pusat TNI Gatot Soebroto Jakarta, pasien dengan keluhan PUA sebanyak 87 dari total 490 pasien. $^{2}$

Umumnya siklus menstruasi 21-35 
hari, durasinya biasanya 5 hari, dan pada 3 hari pertama terjadi kehilangan darah yang banyak. Dalam keadaan tidak hamil, fungsi reproduksi wanita dikontrol oleh sistem kontrol umpan balik negatif dan positif yang kompleks dan siklik antara hipotalamus $(\mathrm{GnRH})$, hipofisis anterior (FSH dan LH), dan ovarium (estrogen, progesteron, dan inhibin).

Gangguan haid sering terjadi pada wanita perimenopause atau post menopause juga pada remaja dan wanita usia reproduksi memiliki manifestasi yang banyak sesuai dengan penyebabnya. PUA merupakan perdarahan yang tidak normal pada uterus menurut waktu, jumlah, dan frekuensi yang bisa terjadi pada saat tidak haid dan sementara haid sehingga membuat penderita merasa tidak nyaman dan dapat berpotensi menggangu aktivitas sehari-hari. Gejalanya terjadi bisa karena adanya gangguan mekanisme dari hipotalamushipofisis-ovarium-endometrium. ${ }^{1}$

PUA pada remaja dapat disebabkan oleh koagulopathy, hypothalamus yang imatur, insufisiensi fungsi luteal, gangguan psikogenik (bulimia dan anoreksia), juga tumor ovarium. Ketika remaja mengeluh tentang PUA, riwayat menstruasi harus ditanyakan, termasuk usia saat menarche, durasi dan jumlah perdarahan uterus. Riwayat gangguan perdarahan pada keluarga dan menstruasi juga penting. Anamnesis tersebut penting untuk keperluan diagnosis dalam menentukan penyebab. ${ }^{1}$

PUA pada peri-menopause atau pascamenopause biasanya terjadi karena kelainan struktur, seperti polip, adenomiosis, leiomioma, malignansi seperti kanker serviks, kanker endometrial atau hiperplasia endometrium. Untuk itu pemeriksaan ginekologi dan Pap-smear sangat diperlukan. ${ }^{2}$

\section{METODE PENELITIAN}

Jenis penelitian ialah deskriptif retrospektif menggunakan data rekam medik pasien di RSUP Prof. Dr. R. D. Kandou Manado periode tahun 2015.

\section{HASIL PENELITIAN DAN BAHASAN}

Data yang diperoleh menunjukkan jumlah pasien PUA seluruhnya pada tahun 2015 di RSUP Prof. Dr. R. D. Kandou Manado sebanyak 62 pasien. Yang memiliki data 26 pasien (data lengkap 17 pasien) sedangkan 36 pasien tidak memiliki data. Data yang dikumpulkan dari catatan rekam medik kemudian disajikan dalam bentuk tabel.

Tabel 1 memperlihatkan kasus PUA terbanyak pada usia 41-50 tahun yaitu 21 kasus $(33,87 \%)$, dan yang paling sedikit pada usia $<20$ tahun dan usia 21-30 tahun dengan masing-masing 6 kasus $(9,68 \%)$. Pada penelitian sebelumnya PUA sering terjadi pada wanita usia reproduksi dan meningkat pada wanita usia perimenopause dan pasca menopause sebanyak $70 \% .^{3}$

Tabel 1. Berdasarkan usia

\begin{tabular}{ccc}
\hline Usia & Jumlah & \% \\
\hline$<20$ & 6 & 9,68 \\
$21-30$ & 6 & 9,68 \\
$31-40$ & 14 & 22,58 \\
$41-50$ & 21 & 33,87 \\
$51-60$ & 7 & 11,29 \\
$>60$ & 8 & 12,90 \\
Total & 62 & 100 \\
\hline
\end{tabular}

Tabel 2 memperlihatkan bahwa berdasarkan indeks masa tubuh (IMT) PUA paling banyak terjadi pada IMT 23,0-24,9 (berat badan lebih) yaitu 6 kasus (30\%), diikuti oleh IMT 25,0-29,9 (obesitas I) dan $\geq 30,0 \quad$ (obesitas II) masing-masing sebanyak 5 kasus (25\%), dan IMT <18,5 (kurus) dan 18,5-22,9 (normal) yaitu masing-masing sebanyak 2 kasus (10\%).

Tabel 2. Berdasarkan IMT

\begin{tabular}{ccc}
\hline IMT & Jumlah & \% \\
\hline$<18,5$ & 2 & 10 \\
$18,5-22,9$ & 2 & 10 \\
$23,0-24,9$ & 6 & 30 \\
$25,0-29,9$ & 5 & 25 \\
$\geq 30,0$ & 5 & 25 \\
Total & 20 & 100 \\
\hline
\end{tabular}

Untuk kejadian PUA berdasarkan IMT masih terdapat 42 data yang tidak ada atau 
belum lengkap. Pada penelitian sebelumnya, dibandingkan dengan wanita yang tidak menderita PUA, wanita dengan PUA cenderung yang berusia 18-30 tahun, tidak pernah menikah, dan obes. ${ }^{4}$

Tabel 3 menunjukkan kejadian PUA berdasarkan klasifikasi PALM-COEIN yaitu kasus terbanyak pada PUA-L sebanyak 8 kasus (40\%), disusul oleh PUAM 4 kasus (20\%), PUA-O 3 kasus (15\%), PUA-A 2 kasus (10\%), PUA-P, PUA- E, dan PUA-I masing-masing 1 kasus $(5 \%)$; tidak terdapat kasus dengan PUA-C dan PUA-N. Berdasarkan klasifikasi PALMCOEIN terdapat 42 data yang belum lengkap atau tidak memiliki data. Wanita dengan fibroid (leiomioma) memiliki prevalensi yang tinggi terkait dengan PUA. Insiden polip seperti fibroid meningkat dengan usia dan keduanya dapat muncul bersamaan. ${ }^{5}$

Tabel 3. Berdasarkan PALM-COEIN

\begin{tabular}{ccc}
\hline PALM-COEIN & Jumlah & \% \\
\hline Polip & 1 & 5 \\
Adenomiosis & 2 & 10 \\
Leiomioma & 8 & 40 \\
Malignansi dan & 4 & 20 \\
hiperplasia & & \\
Koagulopati & 0 & 0 \\
Ovulatory dysfunction & 3 & 15 \\
Endometrial & 1 & 5 \\
Iatrogenic & 1 & 5 \\
Not yet classified & 0 & 0 \\
Total & 20 & 100 \\
\hline
\end{tabular}

Dalam penelitian sebelumnya, ditemukan pasien yang menderita PUA dengan usia 30-70 tahun dan yang memiliki kejadian paling banyak pada umur 41-50 tahun. Dalam grup usia tersebut, adenomiosis yang paling sering ditemukan kemudian diikuti dengan leiomioma. Untuk grup usia yang lebih muda dan grup usia pasca-menopause ditemukan adenomiosis yang paling sering pada wanita dengan POA. ${ }^{6}$ Penelitian lainnya mengenai prevalensi gangguan hemostasis pada remaja dengan PUA menyebutkan prevalensi dari defek koagulasi tinggi pada wanita dengan PUA, terutama pada remaja.
Meskipun von Willebrand disease (VWD) pada populasi umum rendah, tetapi pada wanita dewasa dengan PUA dan remaja dengan PUA prevalensinya tinggi. Umumnya penelitian berfokus pada VWD akan tetapi yang paling sering terjadi pada wanita dengan PUA ialah platelet dysfunction. $^{7}$

Tabel 4 memperlihatkan terdapat 8 pasien yang melakukan pemeriksaan hispatologik $(30,76 \%)$ dan terdapat 18 pasien yang tidak melakukan pemeriksaan histopatologik $(69,24 \%)$. Hasil ini diambil menurut pasien yang memiliki data tersebut tetapi masih ada 36 kasus yang tidak ditemukan datanya di bagian rekam medik. Menurut Bashir et al. ${ }^{17}$ pemeriksaan histopatologik dari biopsi endometrium yang diambil melalui dilatasi dan kuretase (D\&C) menjadi standar diagnosis untuk PUA. $^{17}$

Tabel 4. Berdasarkan pemeriksaan histopatologik

\begin{tabular}{ccc}
\hline $\begin{array}{c}\text { Pemeriksaan } \\
\text { histopatologik }\end{array}$ & Jumlah & $\boldsymbol{\%}$ \\
\hline Ada pemeriksaan & 8 & 30,76 \\
Tanpa pemeriksaan & 18 & 69,24 \\
Total & 26 & 100 \\
\hline
\end{tabular}

Pada Tabel 5 berdasarkan pasien yang memiliki data yang lengkap, pasien dengan penanganan medikamentosa dan D \& C memiliki kasus terbanyak yaitu 9 kasus $(34,62 \%)$ dan operatif dengan 8 kasus $(30,76 \%)$. Masih ada 36 kasus yang tidak ditemukan datanya di rekam medik. Menurut Bashir et al. ${ }^{8} \mathrm{D} \& \mathrm{C}$ harus dipertimbangkan pada semua wanita bila PUA tidak menunjukkan perbaikan dengan penanganan medikamentosa dan terlebih pada wanita dengan usia $\geq 40$ tahun dan wanita yang memiliki faktor risiko tinggi kanker endometrial. Penanganan efektif untuk mengontrol PUA dengan kelainan nonanatomik dapat dilakukan dengan penanganan medikamentosa termasuk terapi hormonal dan nonhormonal. Terapi hormonal menekan perdarahan pada kebanyakan pasien; terapi nonhormonal seperti NSAIDs dan antifibrinolitik juga 
efektif. Penanganan dengan cara operatif direkomendasikan untuk pasien yang tidak memiliki kemajuan dengan terapi sebelumnya atau memiliki kelainan anatomik. ${ }^{3,8}$ Pada penelitian sebelumnya, banyak pengobatan non-operatif untuk PUA yang efektif untuk mengurangi perdarahan pada wanita dengan PUA-E. ${ }^{9}$

Tabel 5. Berdasarkan penanganan

\begin{tabular}{ccc}
\hline Penanganan & Jumlah & \% \\
\hline Medikamentosa & 9 & 34,62 \\
D\&C & 9 & 34,62 \\
Operatif & 8 & 30,76 \\
Total & 26 & 100 \\
\hline
\end{tabular}

\section{SIMPULAN}

Berdasarkan hasil penelitian yang dilaksanakan di RSUP Prof. Dr. R. D. Kandou Manado didapatkan 62 kasus perdarahan uterus abnormal, terbanyak pada usia 41-50 tahun, IMT 23,0-24,9, klasifikasi PALM-COEIN PUA-L, dengan penanganan medikamentosa dan D \& C.

\section{SARAN}

Untuk wanita yang berusia 41-50 tahun dan memiliki berat badan berlebih dianjurkan untuk menurunkan hingga berat badan ideal.

\section{DAFTAR PUSTAKA}

1. Siregar MFG. Management of abnormal uterine bleeding in perimenache: diagnostic challenges. Int J Med Sci Pub Health. 2016;5:597.

2. Kurniawan RH, Abidin St.FA. Diagnostic approach of abnormal uterine bleeding. Jurnal Indonesia Obestetri Ginekologi. 2014;2:106.

3. Matthews ML. Abnormal uterine bleeding in reproductive-aged women. Obstet
Gynecol Clin N. 2015;42:103-13.

4. Matteson KA, Raker CA, Clark MA, Frick KD. Abnormal uterine bleeding, health status, and usual source of medical care: Analyses using the medical expenditures panel survey. 2013 November [cited 16 Nov 2016]. Available from: http://europepmc.org/articles/pmc382 0123

5. Whitaker L, Critchley HOD. Abnormal uterine bleeding. Best Practice and Research Clinical Obstetrics and Gynaecology. 2016;34:56-60.

6. Rizvi G, Pandey H, Pant H, Chufal SS, Pant P. Histopathological correlation of adenomyosis and leiomyoma in hysterectomy specimens as the cause of abnormal uterine bleeding in women in different age groups in the Kumaon region: A retrospective study. Journal of Mid-life Health. 2013;4:27-30.

7. Seravalli V, Linari S, Peruzzi E, Dei M, Paladino E, Bruni V. Prevalence of hemostatic disorders in adolescents with abnormal uterine bleeding. Journal of Pediatric and Adolescents Gynecology. 2013;26:285-89.

8. Bashir H, Bhat N, Khuroo MS, Reshi R, Nazeir MJ, Qureshi MZ. Clinicopathological study of endometrium in patient with abnormal uterine bleeding. Int J Cur Res Rev. 2015;22:67.

9. Matteson KA, Rahn DD, Wheller TL, Casiano E, Siddiqui NY, Harvey HS, et al. Non-surgical management of heavy menstrual bleeding: a systematic review and practice guidelines. 2013 Maret [cited 16 Nov 2016]. Available from: https: //www.ncbi.nlm.nih.gov/pmc/articles/ PMC4414119/ 